\title{
Impact of the Expanded Public Works Programme on Employment Creation and Skills in a South African Metropole Municipality
}

\author{
Tamara Dyantyi and Stanley Fore
}

\begin{abstract}
The main purpose of this research was to assess the impact of EPWP on employment creation and upskilling of its participants in the municipalities so that they may be employable in the job market after they have participated in the programme. This paper firstly, investigated the relevance and the impact of training and skills given to the beneficiaries when they exit the programme. Secondly, this research established an evidence-based conclusion of whether or not the EPWP programme fulfils its mandate of alleviating poverty, improving employability and upskilling its participants.

The research was conducted using qualitative and quantitative methods where a sample size of 87 beneficiaries from four employment sectors in the municipality were requested to complete a self-administered questionnaire and to partake in cross-sectional interviews. The main research finding was that, the majority (59\%) of the participants believed that EPWP programme does fulfil its mandate of alleviating poverty. $55 \%$ of the participants indicated that their financial situation change following participation in the programme. $72 \%$ agreed that EPWP does bring income relief. There was a strong relationship between the overall satisfaction with the programme and the employment duration. A general finding amongst those that were dissatisfied was that the wage income is too little to have an effective impact.
\end{abstract}

Keywords - Employability, EPWP, Job Creation, Municipality, Poverty.

\section{INTRODUCTION}

According to the report by [1], the rate of unemployment in South Africa for the second quarter was $25.5 \%$. The unemployment rate in the local government sector rated 90th out of 179 and is $42 \%$ for people between the age 15 to 34 . Youth unemployment was 52\% or higher in 2014 for the municipalities. In response to the unemployment crisis, on the 1st of April 2004, the government introduced Expanded Public Work Programme (EPWP), which is a national government initiative that provides short-term employment for the unemployed to fight poverty, reduce unemployment and contribute to the country's economic development. The National Department of Public Works has set a target of creating 4.5 million jobs and all three levels of government (National, provincial and local) had to contribute. Municipalities were expected to generate 1.5 million work opportunities between 2009/10 to 2013/14 [4]. In July 2009 the Municipality had an EPWP target of 69692 work opportunities

Paper submitted on 24 August 2019. Tamara Dyantyi and Stanley Fore, Cape Peninsula University of Technology, Faculty of Business, Department of Management and Project Management, Cape Town, South Africa. since its inception. Ever since, the municipality has surpassed its target tremendously and it has received further inducements from the national government. The employment creation attempts through the turn-out of EPWP projects has tremendously increased from 13145 to 26405 amongst the November 2010 and December 2011 financial years [2]

Reference [3] argues that knowing the fairly simple nature of the activities to be executed on EPWP projects, the training given to beneficiaries can barely be expected to generate skillful beneficiaries. He continues to point out that the 8-12 days paid training provided is not enough to train unskilled workers to become skillful.

The table below indicates the relationship between the research questions and the research objectives.

TABLE I: RELATIONSHIP BETWEEN RESEARCH QUESTIONS AND OBJECTIVES

\begin{tabular}{|c|c|}
\hline Research Questions & Research Aim \& Objectives \\
\hline $\begin{array}{l}\text { How relevant is the training } \\
\text { given to EPWP } \\
\text { beneficiaries? }\end{array}$ & $\begin{array}{l}\text { To investigate the relevance } \\
\text { of training given to the } \\
\text { beneficiaries when they exit } \\
\text { these programmes. }\end{array}$ \\
\hline $\begin{array}{l}\text { Does the training and skills } \\
\text { the EPWP beneficiaries } \\
\text { acquire have an impact on } \\
\text { their future employability } \\
\text { when they exit the } \\
\text { programme }\end{array}$ & $\begin{array}{l}\text { To evaluate the impact of the } \\
\text { training and skills that an } \\
\text { EPWP worker acquires } \\
\text { during the work term in } \\
\text { helping the beneficiary to } \\
\text { find formal work after the } \\
\text { expiration of the EPWP } \\
\text { employment term. }\end{array}$ \\
\hline $\begin{array}{l}\text { Does EPWP } \\
\text { fulfil its mandate of } \\
\text { alleviating } \\
\text { improving employment and } \\
\text { upskilling its participants? }\end{array}$ & $\begin{array}{l}\text { To establish the } \\
\text { evidence-based conclusion } \\
\text { of whether or not the EPWP } \\
\text { programme fulfils its } \\
\text { mandate of alleviating } \\
\text { poverty, improving } \\
\text { employment and upskilling } \\
\text { its participants. }\end{array}$ \\
\hline $\begin{array}{l}\text { Are the EPWP beneficiaries } \\
\text { able to sustain decent work } \\
\text { opportunities after they exit } \\
\text { the programme? }\end{array}$ & $\begin{array}{l}\text { To assess if EPWP is the } \\
\text { best alternative in addressing } \\
\text { unemployment? }\end{array}$ \\
\hline
\end{tabular}




\section{UNEMPLOYMENT}

\section{A. Unemployment}

Since 1994, main financial developments and alterations have been made, which were viewed as a necessity for sustaining financial development and growth. Nevertheless, in spite of these efforts, unemployment in South Africa remains a persistent problem [7].

South Africa's high rate of poverty and discrimination can be specifically connected to the country's unemployment crisis. Poverty is clearly leading and is proved by poor infrastructure, unemployment shacks, homelessness, and lack of access to basic services. The period of apartheid worsened the situation when black people were excluded from fiscal contribution because of the class and race [5].

\section{B. Expanded Public Works Programme to alleviate poverty}

The EPWP is a countrywide programme covering all three spheres of government and state-owned enterprises. The programme offers the country a significant opportunity for labour absorption and salary opportunity to underprivileged South Africans in the short to medium-term. This programme started in April 2004 to support the financial development and generate sustainable growth in South Africa [6].

The EPWP's highest goals are to attain its purposes and targets through the distribution of public services by using available government budgets to diminish, improve unemployment and increase the ability of beneficiaries to earn an income, through the labour market or through innovative business activities [6].

The main goal of EPWP was to reduce unemployment for one million people by employing at least $60 \%$ women, $30 \%$ youth and 2\% of disabled beneficiaries between 2004 and 2009 . All three spheres of government from the national, provincial and local government were expected to work together with the Department of Public Works (DPW). During Phase 1, the Programme exceeded its 1 million target of work opportunities a year ahead of planned time frame, with 1.6 million work opportunities generated at the end of the scheduled initial five-year period (2004-2009). EPWP Phase 2, had a target of 4.5 million work opportunities that needed to be created between 2009/10 - 2013/14. This meant that support of EPWP to the Millennium Development Goal (MDG) would half unemployment by 2014 [9]. The EPWP focuses on four sectors below:

- Infrastructure.

- Economic.

- Environmental.

- Social development.

The Expanded Public Works Programme (EPWP) is implemented by and through the above mentioned sectors in all three spheres of government in the national, provincial and local government (Department of Public Works, 2015).

\section{RESEARCH METHODOLOGY}

The population research was formed by all 40055 beneficiaries that participated in the EPWP programme in the 2014/15 financial year. 2014/15 financial year was chosen as it gave adequate buffer time for the participants to find alternative employment. It was also the only period where the previous beneficiaries could be successfully traced and interviewed. A sample was, then calculated as a fraction of this population of 40055 [2].

The study was conducted through structured interviews. A total of 87 respondents from all four employment sectors were interviewed as demonstrated in table below.

The sample size was calculated using the statistic formulae given below as adopted by [8]. This formula is a hypergeometric distribution that calculates sample size as a function of the entire population. The sample size calculation corresponded to the confidence level of $65 \%$, With the accuracy of plus or minus $5 \%$.

TABLE II: POPULATION GROUPS

\begin{tabular}{ccc}
\hline \hline Sector & Population & Percentage \\
\hline Infrastructure & 22 & $25 \%$ \\
Economic & 13 & $15 \%$ \\
Environmental & 29 & $34 \%$ \\
Social & 22 & $26 \%$ \\
\hline \hline
\end{tabular}

This research was conducted using stratified random sampling, where different groups were divided into four EPWP sectors, namely infrastructure sector 22 (25\%), economic sector13(15\%), from environmental sector 29 (34\%), and $22(26 \%)$ from social development to ensure that the entire EPWP population is represented in the sample. Each of these sample sizes was selected randomly from all of these four strata.

\section{FINDINGS}

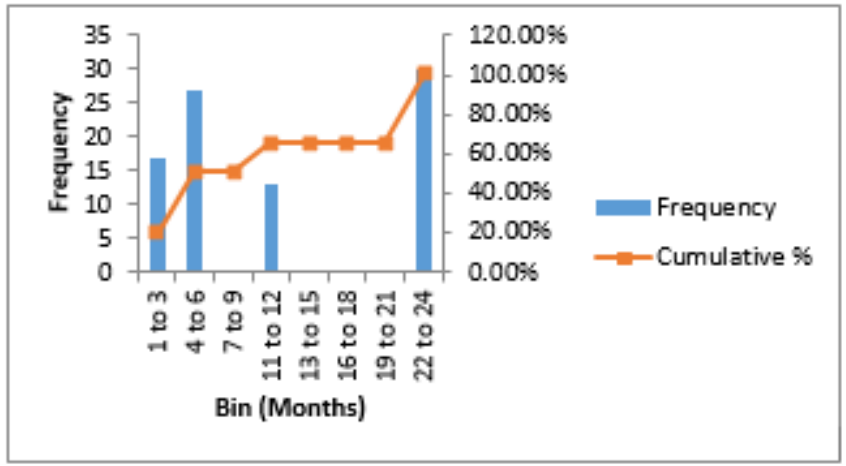

Fig. 1. Cooling-off period.

A very strong relationship was found between those that were unable to find work elsewhere with those that did not receive completion certificates. It can be concluded that the lack of training certificates when exiting the programmes directly contributes to the inability to find alternative employment.

In this study, the respondents were asked if they have received any training while they were working on the programme. It can be seen in figure 2 that $67 \%$ of the respondents indicated that they had not gotten training for the job that they were expected to perform while $33 \%$ indicated 
that they had on the job training. Furthermore, social sector participants received the most training at $12.6 \%$. environmental sector participants received the least training with $13.8 \%$ have stated that they did not receive any relevant prior training for the job they were assigned to do. Infrastructure and social sectors reported the worst in terms of prior training with a respective rate of $18.5 \%$ overall participants have indicated that they never received any prior training.

$33 \%$ of the respondent indicated that they have received training on the project they were working on. This depended on the nature of the activities they had to carry out in a project. For example, the Plumbing Project, Grass Mowing and Facility Protection projects etc. these projects required the respondents to have a level of skills and understanding on how to utilize the machinery.

Did you get any training for the job

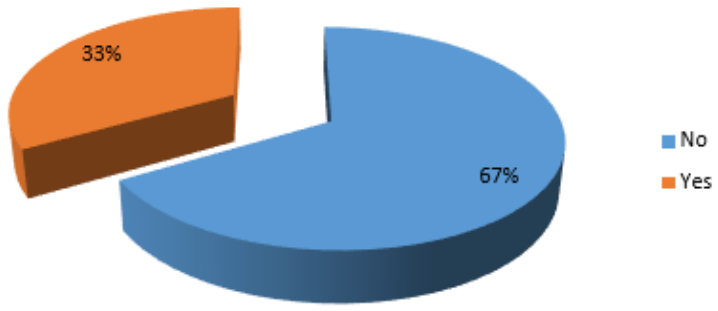

Fig. 2. Job Training.

One of the objectives for conduction the study was to establish whether or not the EPWP programme fulfils its mandate of alleviating poverty, improving employment and upskilling its participants. 59\% believed that EPWP programme does fulfil its mandate of alleviating poverty, while $41 \%$ did not believe that EPWP addressed the poverty problem. Please see figure 3 below.

\section{Does EPWP Help Alleviate Poverty?}

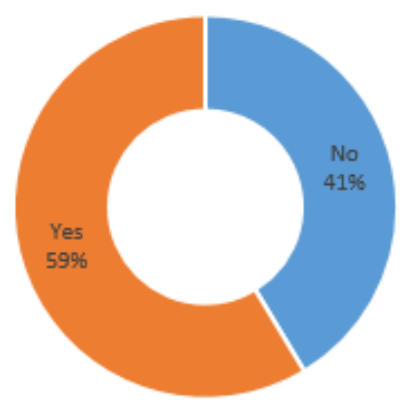

Fig. 3. Role of EPWP in Poverty Alleviation.

Define In this study, all participants were asked if they had received training certificates upon their exit from the programme. Figure 4 indicates the percentage of those that received training certificates vs those that did not receive training certificates. According to the figure below $11 \%$ had received training certificates and $89 \%$ indicated that they had never received training certificates.

\section{Did the participants recieve training certificates}

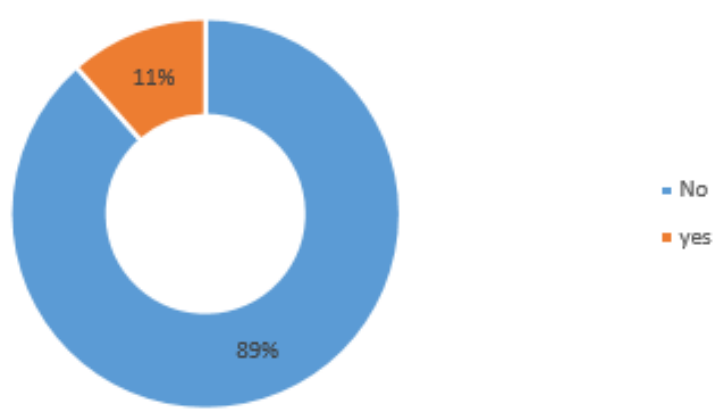

Fig. 4. Training Certificates.

A relationship between receiving a completion certificate and the employment duration was investigated. The premise was that those who stayed longer in the programme are most likely to receive relevant training and ultimately, a training certificate. Although not conclusive, there was some relationship between the employment term and receiving a certificate. Out of those that indicated that they had received completion certificates, there was a participant that had only been employed for a period of 5 months and two participants that had only stayed for 6 months. The average stay of those that received certificates was 14.9 months. Conversely, amongst those participants that did not receive any certificate, there were 6 participants that had a maximum stay of 24 months. The average stay of those that did not receive any certificates was slightly less at 8.3 months. Figure 5 shows a comparison in average participation duration between those that did and those that did not receive participation certificates. Based on this, it can be seen that on average, those that stayed longer in the training programme were most likely to receive a training certificate. In this research, those that received training certificates had stayed an average of more than 6 months than those that did not receive any certificates.

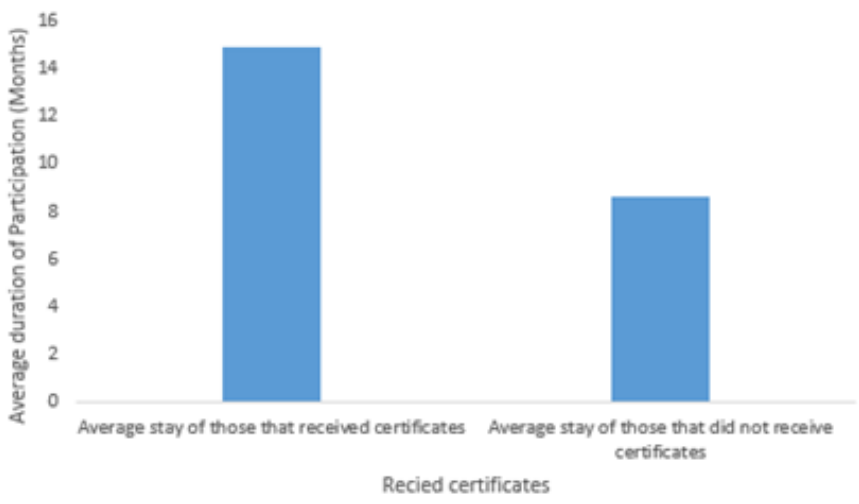

Fig. 5. Relationship between average duration of participation and receiving a training certificate.

In this study, the researcher also investigated the EPWP's ability to provide income relief. Participants were asked whether or not they agreed that their financial situations improved for the better when they participated in the programme. Figure 6 indicates that a majority of $72 \%$ agreed 
that there was some income relief following the participation in the programme. Those that did not believe EPWP brings income relief had worked some comparatively shorter periods than those that indicated that there was some income relief. On average (50th percentile) those that did not agree to an income relief had worked for between 3 to 6 months. On average (50th percentile) those that agreed to an income relief had worked for between 6 to 9 months.

Most of the participants (33) that agreed that the EPWP alleviates poverty stated that they were now able to feed their families after participating in the EPW programme. The most frequent reason for those that did not believe EPWP relieves poverty was because the respondents believed that the income is just too little to have an impact. This is a common finding throughout this research in most categories.

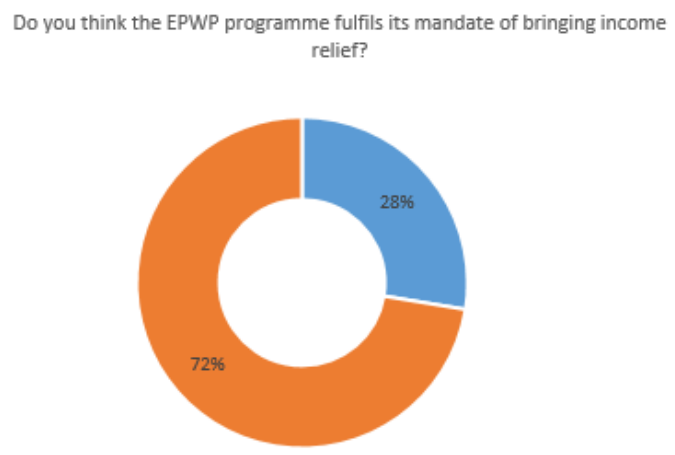

- No

Fig. 6. Role of EPWP in income relief.

In order to understand the employability impact of EPWP, respondents were asked if they were able to find other work. Only $32 \%$ of the participants had responded that they were able to find work after participating in the programme. The $68 \%$ of the participants that could not find work after exiting the programmes shows that the training and skills they have acquired while in the programme were not entirely relevant to the labour market, hence they could not find work after exiting the programme. There is a very strong relationship between those that were unable to find work else with those that did not receive completion certificates. The lack of training certificates when exiting the programmes directly contributes to non-employment. Figure 7 shows the results.

\section{Were you able to find employment elsewhere?}

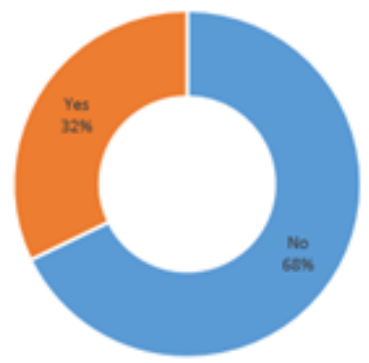

Fig. 7. Role of EPWP in Employability.

When overall satisfaction with the EPWP was considered, the findings showed that $23 \%$ of the respondents were very satisfied. And $24 \%$ of the respondents indicated that their overall experience with EPWP was satisfactory. $11 \%$ were highly dissatisfied while $13 \%$ indicated that they were not satisfied. $29 \%$ of the respondents indicated that their experience was neutral, thus inconclusive. Figure 8 shows the level of satisfaction amongst the participants.

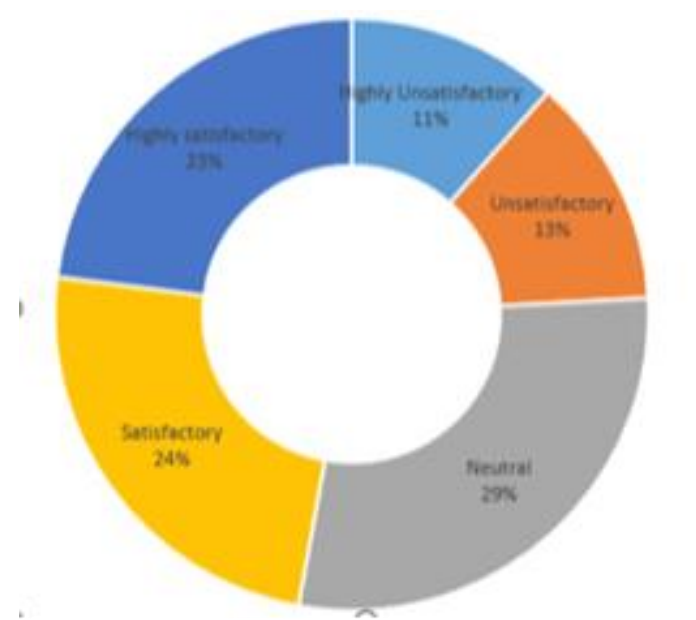

Fig. 8. Overall Satisfaction.

\section{RECOMMENDATIONS}

\section{A. Recommendations to the municipality}

The This study made the following recommendations to the municipality in order to improve its EPW programme according the findings presented in this research:

1) Those that did not agree that EPWP brings about income relief, believed that the income is too little to have an impact and bring income relief. Based on this finding it is recommended to consider increasing the minimum daily wage rate annually with inflation in order for EPWP to better fulfil its mandate of poverty alleviation.

2) It is recommended that the minimum participation period is increased to a period longer than 3 months in order to ensure that EPWP does bring income relief to most of its participants and to also facilitate skills development

3) It is recommended that municipality designs labour-intensive projects that will provide the beneficiaries with appropriate necessary skills that are relevant to the labour market in order for them to acquire relevant skills and be employable in the labour market when they exit the programme.

4) It is recommended that municipality heightens its commitment to prior training before participants commence with the task.

5) It is recommended that training certificates be provided when the project is completed in order to improve the participants' likelihood of obtaining alternative employment on the job market.

6) In line with the recommendation above, it is recommended that project managers be trained to be committed to training and development.

\section{B. Suggestions by the applicants}

The participants were asked to suggest recommendations in 
order to make the programme more impactful and for it to fulfil its mandate. Each participant could provide more than one recommendation. Table 2 below summarizes the suggestions.

TABLE II: POPULATION SUGGESTIONS BY THE PARTICIPANTS TO IMPROVE EPWP

\begin{tabular}{|l|l|l|}
\hline \multicolumn{1}{|c|}{ Recommended Suggestions } & Number & \% \\
\hline Increase salary & 46 & $37.70 \%$ \\
\hline Give longer contracts & 14 & $11.48 \%$ \\
\hline $\begin{array}{l}\text { More Skills and Training } \\
\text { Development }\end{array}$ & 13 & $10.66 \%$ \\
\hline Increase contract duration & 12 & $9.84 \%$ \\
\hline $\begin{array}{l}\text { Employ more people and make } \\
\text { them permanent }\end{array}$ & 8 & $6.56 \%$ \\
\hline Improve PPE & 6 & $4.92 \%$ \\
\hline Permanent employment & 6 & $4.92 \%$ \\
\hline No Comment & 4 & $3.28 \%$ \\
\hline Career guidance & 3 & $2.46 \%$ \\
\hline Improve PPE & 2 & $1.64 \%$ \\
\hline Better working conditions & 1 & $0.82 \%$ \\
\hline Career guidance & 1 & $0.82 \%$ \\
\hline & 122 & $100.00 \%$ \\
\hline
\end{tabular}

\section{CONCLUSIONS}

This study`s main purpose was to evaluate the influence that the EPWP has on job creation and upskilling of its beneficiaries in the municipality Metropolitan Municipality with the goal that they may obtain skills that will make them employable in the labour market.

The majority $(55 \%)$ of the participants indicated that their financial circumstances improved after they took part in the programme. However, those whose financial circumstances change were also considerable at $45 \%$. Based on the research question 3, it can be concluded that the programme somewhat does fulfil its mandate of poverty alleviation.

The majority of $72 \%$ also indicated that the EPWP does bring income relief. Only $28 \%$ of the respondents indicated that the EPWP does not bring income relief. Those that did not believe EPWP brings income relief had worked some comparatively shorter periods than those that indicated that there was some income relief. It can be concluded, therefore that in terms of research question 3, the EPWP does fulfil its mandate of alleviating poverty.

Only $32 \%$ of the participants were able to find work elsewhere while $68 \%$ were unable to find work. The $68 \%$ of the participants that could not find work after exiting the programmes shows that the training and skills they have acquired while in the programme were not entirely relevant to the labour market, hence they could not find work after exiting the programme. It can therefore be concluded that, based on this study, the acquired skills from EPWP have little impact in enhancing future employability of its participants.

Only $11 \%$ had received training certificates and $89 \%$ indicated that they had never received training certificates after completing their training, the poor impact of EPWP in future employability as highlighted above can be attributed to the lack of certificate at the end of the programme.

The sum of those that are somewhat satisfied with the programme (47\%) exceeds the sum of those that are dissatisfied
(24.14\%) when the "neutral" respondents are not considered. Based on these figures, it can be concluded that there is an overall satisfaction with EPWP participation by the respondent's.

\section{ACKNOWLEDGMENT}

S. Fore thank you so much for your assistance and patience, I would not have made it without out you. S. Mdlangaso thank you so much for the unwavering support you have given me throughout my research. I appreciate the time you spent, editing and making meaningful contributions to this research.

\section{REFERENCES}

[1] D. Dube, "Expanded Public Works Programme's Contribution to Social Development: Opportunities and Challenges. Master's Thesis," University of the Witwatersrand, 2013.

[2] City of Cape Town, 2016. "I Massive Jump in South African unemployment rate," [Online]

available:http://cityweb.capetown.gov.za/en/achievementsandawards/Pa ges/CitysAnnualRep201011thisCityworkingforyou.aspx/ [Accessed:03 August 2016]

[3] C. Meth, "Employer of Last Resort? South Africa's Expanded Public Works Programme (EPWP). A Southern Africa Labour and Development Research Unit Working," Cape Town: SALDRU, University of Cape Town., pp. 58, 2011.

[4] Statistics South Africa, 2017. Quarterly Labour Force Survey Quarter 43, 1st ed. Chichester, [Online] available:

http://www.statssa.gov.za/?p=10658 [Accessed:31 October 2017].

[5] C.T. Malakwane, "Economic and social effects of unemployment in South Africa: prospects for the future". Master`s. dissertation, Tshwane University of Technology, 2012.

[6] Department of Public Works, 2011. Expanded Public Works Programme Vuk uphile creating work opportunities; Pretoria: Government printer

[7] L. Steenkamp, 2015. "South Africa's economic policies on unemployment: A historical analysis of two decades of transition, Degree Thesis, North-West University.

[8] E, Morris, Undated. G "Sampling from Small Populations," http://uregina.ca/ morrisev/Sociology/Sampling\%20from\%20small\%20 populations.htm. [Accessed: 20 Sep 2012].

[9] Department of Public Works, 2011. Expanded Public Works Programme Annual Report 2015/2016; Pretoria: Government printer.

[10] A.M. Gafane, "The impact of exit strategy in expanded public works programmes in Tzaneen area," Masters. dissertation, Limpopo province., University of Limpopo, 2011

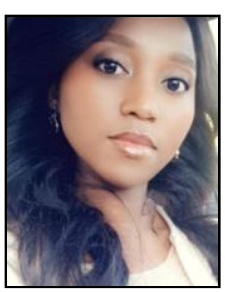

Ms. Tamara Dyantyi is a Project Manager at City of Cape Town under Spatial Planning and Environment: PMO. Before joining the PMO she worked for the Recreation and Parks Department under EPWP unit as a Professional Officer for four years. She has graduated for BTech in Project Management in 2013, BTech in Public Management in 2012 and a Diploma in Public Management in 2011 from Cape Peninsula University of Technology. She is currently completing her Master's in Business Administration in Project Management at the same institution..

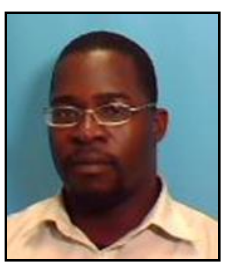

Mr. Stanley Fore is a Lecturer in the Department of Project Management at Cape Peninsula University of Technology (CPUT); department of Project Management. He lectures Project Management to undergraduate and post graduate students. To date, he has successfully supervised several MTech Project Management students. Prior to joining CPUT, he has lectured at other institutions. He holds an MSc in Manufacturing Systems and Operations Management (MSOM), from the University of Zimbabwe. His research interests are in environmental management and operations management and project management with a focus on developing countries 